\title{
CURRENT DEVELOPMENTS IN TRANSPORT MEDIA FOR AVULSED TEETH: AN UPDATE
}

\author{
SHREYA HEGDE, ROMA M* \\ Department of Conservative Dentistry and Endodontics, Manipal College of Dental Sciences, Manipal University, Mangalore, Karnataka, \\ India. Email: enettem20@gmail.com
}

Received: 13 October 2016, Revised and Accepted: 26 October 2016

\section{ABSTRACT}

Dental avulsion is one of the common types of trauma that results in the complete displacement of tooth from the alveolar socket. Although the ideal treatment would be the immediate reimplantation of the tooth at the site where the trauma took place, this may not be practically possible in every case. Hence, the avulsed tooth may have to be placed in an appropriate storage or transport medium until it is reimplanted. The biological properties of the storage medium have a significant impact on the success of reimplantation, as it must be capable of preserving the vitality, clonogenic, and mitogenic ability of the periodontal ligament cells for successful reimplantation.

Keywords: Dental trauma, Avulsed teeth, Storage media, Periodontal ligament cell viability, Transport media.

(C) 2017 The Authors. Published by Innovare Academic Sciences Pvt Ltd. This is an open access article under the CC BY license (http://creativecommons. org/licenses/by/4. 0/) DOI: http://dx.doi.org/10.22159/ajpcr.2017.v10i2.15663

\section{INTRODUCTION}

Avulsion is defined as the complete displacement of the tooth out of its socket. This kind of dental trauma causes the periodontal ligament (PDL) fibers to be severed with or without fracture of the alveolus [1,2]. Reported incidence of dental avulsion is $1-11 \%$ of all dental injuries to the permanent dentition, with the maxillary central incisor being the most frequently involved tooth. The age group of 7-10 years appears to be most affected [3]. A variety of factors such as age of the individual, stage of the root development, mechanical damage during trauma and replantation, treatment of the socket, type of splinting, mastication, endodontic treatment, antibiotics, time of replantation, extraoral dry time, macroscopic contamination, and storage media and storage period are important and can influence the clinical success of replantation [4].

The ideal storage medium should have the capability of preserving the cellular PDL so that the cells could go through the process of mitosis, and form clones of the damaged fibroblasts of the PDL, and its generating cells. This is essential so that the nude surface of the root be repopulated with fibroblasts, thus, avoiding the adherence of osteoclasts on this area. An ideal storage medium should preserve the majority of the functional capacities of the cells of the PDL [5].

The way by which the tooth is transported also affects significantly the degree of success. The root of the tooth should not be touched, for each time this happens, the cells of the PDL are damaged and they die. The container used for the transport of avulsed teeth must be unbreakable, nontoxic, leak proof and of easy handling, with internal walls made of soft material, sterile and it must protect the tooth during transport, besides making the removal of the tooth easy without any trauma [6]. The present review summarizes the role of storage media in periodontal healing, the available media and the ongoing developments in this field.

\section{VARIOUS STORAGE MEDIA}

\section{Tap water}

Tap water is an unacceptable storage media for avulsed teeth. Blomlof et al. found that storing cultured human PDL cells in tap water for $1 \mathrm{hr}$ caused more PDL cell damage than the other physiological and nonphysiological storage media tested. They attributed that increased cell damage to the cell lysis caused by the very low osmolarity of tap water [7]. Among the studied environments, tap water has shown to be the one with the least desirable results, though it protects the tooth from dehydration - for being a hypotonic medium - it causes rapid cellular death of the PDL, similarly to a dry storage [8].

\section{Normal saline (NS)}

NS is a solution of $0.90 \% \mathrm{w} / \mathrm{v}$ of sodium chloride, and osmolality of $280 \mathrm{mOsm} / \mathrm{kg}$ and despite being compatible to the cells of the PDL, it lacks essential nutrients such as magnesium, calcium, and glucose; necessary to the normal metabolic needs of the cells of the PDL [6]. Cvek et al. found that avulsed teeth soaked in an isotonic saline for 30 minutes before replantation showed less resorption than those stored dry between 15 and 40 minutes [9]. They proposed that if an avulsed tooth has been kept dry for more than 15 minutes, it should be stored in an isotonic saline solution for about 30 minutes before replantation, presuming that PDL cells might be reconstituted or reconditioned by this procedure but in contrast Andreasen and Schwartz observed that following a 30 minute dry period, saline storage under experimental conditions has no effect on the development of root resorption and pulpal repair presumably because within 30 minutes maximal damage to the PDL has been inflicted [10].

\section{Saliva}

Saliva can be used as a storing medium for a short period, for it can damage the cells of the PDL if used for longer than an hour. Its osmolality $(60-70 \mathrm{mOsm} / \mathrm{kg})$ is much lower than the physiologic, thus, storage of avulsed teeth in saliva for 2-3 hrs causes swelling and membrane damage of PDL cells and also the presence of microorganisms makes saliva a less desirable storage medium [11]. Although readily and most easily available, saliva is not considered an effective interim transport medium. Recent literature indicates that saliva may not be a suitable transport medium for avulsed teeth due to its nonphysiologic osmolarity and the presence of microorganisms [12].

\section{Milk}

Milk is considered as one of the suitable storage medium for avulsed teeth, as it presents physiologically compatible $\mathrm{pH}$ and osmolarity, essential nutrients, growth factors besides being easily accessible [13]. Milk is significantly better than other solutions for its physiological properties, including $\mathrm{pH}$ and osmolality. It is also considered compatible to the cells from the PDL; the easy way of obtaining it and for being 
bacteria free, but it is important that it is used in the first 20 minutes after avulsion. The favorable results of milk probably occur due to the presence of nutritional substances such as amino acids, carbohydrates, and vitamins. The pasteurization of milk is responsible for diminishing the number of bacteria and bacteriostatic substances also for the inactive presence of enzymes, which could be potentially harmful to the fibroblasts of the PDL [6].

\section{Gatorade}

Gatorade is a brand of sports-themed food and beverage products manufactured by PepsiCo and distributed in over 80 countries. It consists of a mixture of water, sodium, sugar, potassium, phosphate, and lemon juice. According to Chamorro et al. [14] when cells are exposed to Gatorade, it is possible that the delicate cellular membrane gets damaged because of the low $\mathrm{pH}$, which makes it impossible for the cells to grow. As for osmolality, Gatorade is hypertonic, it can make the cells lose water. Gatorade preserves more viable cells than tap water but fewer than all other media, both at room temperature and on ice. Gatorade is often available at sporting events but it has incompatible, harmful osmolality that causes cell destruction, so it is not an ideal solution to use.

\section{Coconut water}

Coconut water is biologically pure, sterile and rich in amino acids, proteins, vitamins, and minerals. It has been widely consumed to replace fluids, electrolytes (potassium, calcium, and magnesium), and sugars lost from the body during heavy physical exercise. This natural isotonic fluid having $\mathrm{pH}$ of 4.1 is available in its natural form directly from the coconut or in long shelf life packages and plastic bottles mainly available in several geographical locations worldwide. This is the reason, its use as a storage medium for avulsed teeth has been investigated recently. More recently, biologically pure tender coconut water, which aids in replenishing the fluids, electrolytes, and sugars lost from the body during heavy physical work, has been suggested as a promising storage medium for avulsed teeth [15].

\section{Contact lens solution}

Contact lens solution is one of the convenient preservation medium for teeth after avulsion injuries. These solutions are available in school or athletic grounds and at home, where most injuries occur. They contain buffered, isotonic saline solutions with the addition of preservatives that may preserve the viability of PDL cells. Although various single bottle systems (SoftWear ${ }^{\circledR}$, Ciba Vision Opti Care) have been examined as potential temporary storage media for avulsed teeth, no significant difference has been detected in the ability of different contact lens solutions to maintain the cell viability [16]. However, subsequent studies showed that these solutions were damaging to PDL cells, and therefore, they are not recommended [17]

\section{Ascorbic acid}

In addition of ascorbic acid to osteoblastic cell lines can stimulate Type I collagen production, followed by expression of specific markers associated with osteoblastic phenotypes such as alkaline phosphatase (ALP) and osteocalcin. It is also required for in-vitro mineralized nodule formation of osteoblasts. Ishikawa et al. studied the effect of ascorbic acid on PDL cells and observed that ascorbic acid increased the ALP activity, which is required for the binding of PDL cells to Type I collagen through 2 beta 1 integrin, whose expression is again increased by ascorbic acid. As Type I collagen production is considered an initial process in the differentiation of PDL cells, it may serve as a potential storage medium [18].

\section{Hank's balanced salt solution (HBSS)}

Hank's balanced salt solution is a standard saline solution that is widely used in biomedical research to support the growth of many cells types. This solution is nontoxic; biocompatible with PDL cells, $\mathrm{pH}$ balanced at 7.2 and has an osmolality of $320 \mathrm{mOsm} / \mathrm{kg}$. It is composed of $8 \mathrm{~g} / \mathrm{L}$ sodium chloride; $0.4 \mathrm{~g} / \mathrm{L}$ of D-glucose; $0.4 \mathrm{~g} / \mathrm{L}$ potassium chloride; $0.35 \mathrm{~g} / \mathrm{L}$ sodium bicarbonate; $0.09 \mathrm{~g} / \mathrm{L}$ sodium phosphate;
$0.14 \mathrm{~g} / \mathrm{L}$ potassium phosphate; $0.14 \mathrm{~g} / \mathrm{L}$ calcium chloride; $0.1 \mathrm{~g} / \mathrm{L}$ magnesium chloride; and $0.1 \mathrm{~g} / \mathrm{L}$ magnesium sulfate. It contains ingredients such as glucose, calcium, and magnesium ions which can sustain and reconstitute the depleted cellular components of the PDL cells [6]. Krasner and Person have developed an avulsed tooth storage system and emergency tooth preserving system (SAVE-A-TOOTH ${ }^{\circledR}$, Pottstown, PA, USA), which contains HBSS, a net for holding the tooth atraumatically and a container for taking the submerged tooth to a clinician. It is a desirable storage medium for avulsed teeth, even when the extra-alveolar period is extensive (between 72 and $96 \mathrm{hrs}$ ) [19].

\section{ViaSpan}

The ViaSpan (Belzer VW-CSS, DuPont Pharmaceuticals, and Wilmington, DE, USA) is a medium used for the transportation of organs which are going to be transplanted and it has been considered effective for storing avulsed teeth. ViaSpan has osmolality of $320 \mathrm{mOsm} / \mathrm{kg}$ and $\mathrm{pH}$ is around 7.4 at room temperature; ideal for the cellular growth. Hiltz and Trope have compared the vitality of lip fibroblasts, at room temperature $37^{\circ} \mathrm{C}$ (Biological Industries) and recommended it as one of the storage medium, as it can preserve the PDL for extended periods before replantation [20].

\section{Growth factors}

The use of polypeptide growth factors, which function as potent biological mediators regulating numerous activities of wound healing, has been suggested for the promotion of PDL regeneration. Lynch et al. demonstrated that short-term application of a combination of plateletderived growth factor and insulin-like growth factor can enhance the formation of the periodontal attachment apparatus 5-10 fold during the early phase of wound healing. Matsuda et al. studied the effects of individual and a combination of growth factors on PDL fibroblasts [21,22].

\section{Emdogain}

Emdogain diminishes the percentage of fibroblasts of the PDL with capability of forming colonies and that lowers the capability for the fibroblasts to repopulate the dental radicular surface after dental avulsion. The diminishing can happen due to the lack of an adherent surface or in the increase in the differentiation of fibroblasts, which grow in its presence. Emdogain increased the difference on the cells of mineralized tissues. In cases of periodontitis, Emdogain has improved the periodontal recovering after surgeries. In contrast, the posttraumatic periodontal healing needs contrary differentiation. Emdogain can delay, but not stop the development of replacement resorption, which is one of the worst complications of dental trauma. Emdogain on its own is not efficient in the regeneration of injured periodontal tissues of the avulsed tooth [23].

\section{Egg white}

Khademi et al. have compared milk and egg white as solutions for storing avulsed teeth, and the results have shown that teeth stored in egg white for 6-10 hrs had a better incidence of repair than those stored in milk for the same amount of time $(\mathrm{p}<0.05)$. The osmolality of the egg white is between 251 and $298 \mathrm{m0sm} / \mathrm{kg}$ [24]. de Sousa et al. have microscopically analyzed, the human PDL attached to the extracted tooth after $1 \mathrm{hr}$ of extra alveolar time, compared to milk, egg white, and artificial saliva. The results of teeth stored in milk and egg white were similar concerning the organization of collagen fibers and the number of cells. Artificial saliva had an inferior result. The authors suggest that egg white can be considered as the perfect medium for storing avulsed teeth [25].

\section{L-DOPA}

L-DOPA (Levodopa; Sigma Chemicals, Perth, WA, Australia) is a drug with possible mitogenic effects. Levodopa stimulates dopaminergic systems in the anterior portion of the pituitary gland to secrete growth hormone, which is considered as a promoter of the healing process. Partovi et al., observed the effect of levodopa on human PDL fibroblasts and indicated that levodopa can also have a local effect on the growth of cells, including the PDL cells, and can be used as a preserving medium for avulsed teeth [26]. 
Cryoprotective agents

The effect of low temperature storage on the clinical success of replantation has been studied. Mature teeth can be replanted after cryopreservation and can heal in-vivo with a normal PDL, provided that a cryopreservative is used. Schwartz and Andreasen studied the effects of the cryopreserving agents (cryoprotectives) 5\% and 10\% dimethyl sulfoxide and $10 \%$ glycerol, on PDL. They observed that the use of different cryoprotectives, combined with controlled freezing rates to $-196^{\circ} \mathrm{C}$, can preserve the PDL of the replanted teeth to a greater or lesser extent [27].

\section{Green tea}

Green tea is the second most consumed drink in the world, losing only to water. Due to this fact, the effectiveness of the green tea extract (GTE) to maintain PDL cell viability was assessed and showed similar results to HBSS and better than milk. The presence of catechin in GTE, an antioxidant agent highly effective in the maintenance of cell viability, antibacterial, and anti-inflammatory properties, might explain the better result than HBSS, but this has to be confirmed by future studies, as its efficacy to prevent root resorption [28].

\section{Propolis}

Propolis is a natural wax-like resinous substance found in bee hives, which is utilized by the bees as a "chemical weapon" against pathogenic microorganisms. Propolis is a mixture of plant resins and bee secretions. It has a great variety of pharmacological effects such as antimicrobial, anti-inflammatory, immune-modulatory, antiulcer, and antitumor properties, and it is relatively nontoxic. Propolis has a complex chemical composition and is mainly composed of resin (50\%), wax (30\%), essential oils (10\%), pollen (5\%), and other organic compounds (5\%). The application of propolis as a storage media has been studied by many authors [29-31]. Propolis has synergistic effect with Dulbecco's modified eagle's medium (DMEM) for the maintenance of cell viability and preservative potential. In combination, $10 \%$ propolis with DMEM was found to be better than $20 \%$ propolis with DMEM, which shows that $20 \%$ concentration of propolis might have some cytostatic/cytotoxic effect on the cell physiology [32]. Propolis has also been proposed to inhibit the osteoclastic resorption of teeth, which is common sequel of replantation of teeth. Propolis inhibits some aspects of the pathway leading to mature, active osteoclasts [33]. It is used for many dental implications such as pulp capping agent, mouthwash, intracanal irrigant, cariostatic agent, dentinal hypersensitivity, and treatment of periodontitis, treatment of dental stomatitis and as an intracanal medicament.

\section{Catalase supplementation}

Buttke and Trope observed that supplementation with catalase resulted in a significant reduction of surface resorption. It is suggested that the roots stored in antioxidant, demonstrate lower levels of surface resorption. As some storage media contain hydrogen peroxide, which may be toxic to PDL cells, addition of an antioxidant such as catalase can have beneficial effects on PDL cells [34].

\section{Red mulberry}

Red mulberry (Morus rubra) is common from the temperate to the subtropical regions of the northern hemisphere to the tropics of the southern hemisphere. It can grow in a wide range of climatic, topographical and soil conditions. Mulberry fruits are used medicinally as a deworming agent, as a remedy for dysentery, as a laxative, odontalgic, expectorant, hypoglycemic, and emetic. Red mulberry has been recommended as a storage media for avulsed teeth by Ozan et al. They compared four different concentrations of $M$. rubra $(4 \%, 2.5 \%$, $1.5 \%$, and $0.5 \%$ ) with HBSS and tap water at $1 \mathrm{hr}, 3 \mathrm{hrs}, 6 \mathrm{hrs}, 12 \mathrm{hrs}$, and 24 hrs to check the effect on PDL viability. The number of viable PDL cells was significantly high when an avulsed tooth was stored in $4.0 \%$ concentrated solution of $M$. rubra as compared to other concentrations [35].

\section{Pomegranate juice}

Pomegranate effects the fibroblast cell proliferation. This proliferative effect is found for $1 \mathrm{hr}$ at lower concentrations of $1 \%$ and $2.5 \%$, but at
$5 \%$ and $7.5 \%$ concentration a general proliferative effect is exhibited. The peak increase in cell viability is observed at $6 \mathrm{hrs}$. It also promotes strong cell attachment. Pomegranate juice and HBSS can preserve the spindle such as morphology of periodontal fibers for $24 \mathrm{hrs}$ after storage. Hence, it can be a good storage media. Since research conducted to assess its efficacy is very less, further research is needed [36].

\section{Aloe vera}

$A$. vera is a cactus such as plant that belongs to family Liliaceae. The inner gel of $A$. vera has issue of dry period. The dry period should be as less as possible and it would be better if immediate replantation can be achieved. As a fact, it is not always possible to replant the tooth immediately, so, the need for storage media arises. The delay in replantation can vary from few minutes to hours, as in cases of accidents, emergencies and unavailability of dentists, so a storage media which can maintain the PDL cell viability for a long duration is needed $[32,37]$.

\section{Oral rehydration solutions}

Ricetral is a commercially available oral rehydration formulation, consisting of essential nutrients such as glucose and vital salts which help in maintaining cell metabolism. They are marketed in sealed sterile pouches and easily available over the counter in addition to being economical. It does not promote cell mitosis and regenerative capacity of the PDL fibroblasts. Its ability to maintain PDL cell viability was demonstrated to be equal to HBSS in a study, both retaining PDL vitality better than milk [38]

\section{Dentosafe}

Dentosafe (Miradent, Germany) is the commercial name of a tooth rescue box containing special cell culture medium which is a combination of amino acids, vitamins, and glucose [39]. In the USA, it is marketed as EMT Tooth Saver (Phoenix, USA). It has demonstrated the maintenance of vitality of PDL cells for $48 \mathrm{hrs}$ at room temperature [40]. If unopened, this medium has a shelf-life of 3 years. A study by Pohl et al. showed that avulsed teeth placed in Dentosafe solution showed functional healing and recommended that Dentosafe should be included in all first aid kits, especially in locations prone to tooth avulsion injuries such as schools, sports ground and facilities, and public pools as well as emergency units such as hospitals and ambulances. The use of this system is self-explanatory and simple to understand for lay persons. Although effective, this medium is still not easily available in many countries [41].

\section{CONCLUSION}

An appropriate storage media can help maintain the viability of PDL cells and can lead to successful replantation of avulsed teeth. The natural products such as coconut water, milk, and propolis can act as appropriate storage media because of their easy availability and potential to maintain the viability of PDL cells for longer durations. Although research has been undertaken on a wide variety of materials to be used as storage media for the transport of avulsed teeth, lack of availability and high cost limit the use of the majority of these media.

\section{REFERENCES}

1. Holan G, McTigue D. Introduction to dental trauma: Managing traumatic injuries in the primary dentition. Pediatric Dentistry: Infancy Through Adolescence. $4^{\text {th }}$ ed. St. Louis, MO: Elsevier Saunders; 2005. p. 236-56.

2. McTigue DJ. Managing traumatic injuries in the young permanent dentition. Pediatric Dentistry: Infancy Through Adolescence. $4^{\text {th }}$ ed. St. Louis, MO: Elsevier Saunders; 2005. p. 593-607.

3. Trope M. Avulsion and replantation. Refuat Hapeh Vehashinayim 2002;19(2):6-15, 76

4. Andreasen JO, Borum MK, Jacobsen HL, Andreasen FM. Replantation of 400 avulsed permanent incisors 2. Factors related to pulpal healing. Endod Dent Traumatol 1995;11(2):59-68.

5. Hammarström L, Pierce A, Blomlöf L, Feiglin B, Lindskog S. Tooth avulsion and replantation - A review. Endod Dent Traumatol 1986;2(1):1-8.

6. Bazmi BA, Singh AK, Kar S, Mubtasum H. Storage media for avulsed 
tooth - A review. Indian J Multidiscip Dent 2013;3(3):741-9.

7. Mackie IC, Worthington HV. An investigation of replantation of traumatically avulsed permanent incisor teeth. $\mathrm{Br}$ Dent $\mathrm{J}$ 1992;172(1):17-20.

8. Gopikrishna V, Baweja PS, Venkateshbabu N, Thomas T, Kandaswamy D. Comparison of coconut water, propolis, HBSS, and milk on PDL cell survival. J Endod 2008;34(5):587-9.

9. Cvek M, Granath L, Holender L. Treatment of non-vital permanent incisors with calcium hydroxide. 3. Variation of occurrence of ankylosis of reimplanted teeth with duration of extra-alveolar period and storage environment. Odontol Revy 1974;25(1):43-56.

10. Andreasen JO, Schwartz O. The effect of saline storage before replantation upon dry damage of the periodontal ligament. Endod Dent Traumatol 1986;2(2):67-70.

11. Harkacz OM Sr, Carnes DL Jr, Walker WA $3^{\text {rd }}$. Determination of periodontal ligament cell viability in the oral rehydration fluid Gatorade and milks of varying fat content. J Endod 1997;23(11):687-90.

12. Malhotra N. Current developments in interim transport (storage) media in dentistry: An update. Br Dent J 2011;211(1):29-33.

13. dos Santos CL, Sonoda CK, Poi WR, Panzarini SR, Sundefeld ML, Negri MR. Delayed replantation of rat teeth after use of reconstituted powdered milk as a storage medium. Dent Traumatol 2009;25(1):51-7.

14. Chamorro MM, Regan JD, Opperman LA, Kramer PR. Effect of storage media on human periodontal ligament cell apoptosis. Dent Traumatol 2008;24(1):11-6.

15. Gopikrishna V, Thomas T, Kandaswamy D. A quantitative analysis of coconut water: A new storage media for avulsed teeth. Oral Surg Oral Med Oral Pathol Oral Radiol Endod 2008;105(2):e61-5.

16. Pettiette M, Hupp J, Mesaros S, Trope M. Periodontal healing of extracted dogs' teeth air-dried for extended periods and soaked in various media. Endod Dent Traumatol 1997;13(3):113-8.

17. Trope M, Friedman S. Periodontal healing of replanted dog teeth stored in Viaspan, milk and Hank's balanced salt solution. Endod Dent Traumatol 1992;8(5):183-8.

18. Ishikawa S, Iwasaki K, Komaki M, Ishikawa I. Role of ascorbic acid in periodontal ligament cell differentiation. J Periodontol 2004;75(5):709-16.

19. Krasner P, Person P. Preserving avulsed teeth for replantation. J Am Dent Assoc 1992;123(11):80-8

20. Ashkenazi M, Marouni M, Sarnat H. In vitro viability, mitogenic and clonogenic capacities of periodontal ligament cells after storage in four media at room temperature. Endod Dent Traumatol 2000;16(2):63-70.

21. Lynch SE, de Castilla GR, Williams RC, Kiritsy CP, Howell TH, Reddy MS, et al. The effects of short-term application of a combination of platelet-derived and insulin-like growth factors on periodontal wound healing. J Periodontol 1991;62(7):458-67.

22. Matsuda N, Lin WL, Kumar NM, Cho MI, Genco RJ. Mitogenic, chemotactic, and synthetic responses of rat periodontal ligament fibroblastic cells to polypeptide growth factors in vitro. J Periodontol 1992;63(6):515-25.

23. Ashkenazi M, Shaked I. In vitro clonogenic capacity of periodontal ligament fibroblasts cultured with emdogain. Dent Traumatol 2006;22(1):25-9

24. Khademi AA, Atbaee A, Razavi SM, Shabanian M. Periodontal healing of replanted dog teeth stored in milk and egg albumen. Dent Traumatol 2008;24(5):510-4

25. de Sousa HA, de Alencar AH, Bruno KF, Batista AC, de Carvalho AC. Microscopic evaluations of the effect of different storage media on the periodontal ligament of surgically extracted human teeth. Dent Traumatol 2008;24(6):628-32.

26. Partovi M, Sadeghein A, Azizi E, Ostad SN. Mitogenic effect of L-dopa on human periodontal ligament fibroblast cells. J Endod 2002;28(3):193-6.

27. Schwartz O, Andreasen JO. Cryopreservation of mature teeth before replantation in monkeys (I). Effect of different cryoprotective agents and freezing devices. Int J Oral Surg 1983;12(6):425-36.

28. Yang CS, Maliakal P, Meng X. Inhibition of carcinogenesis by tea. Annu Rev Pharmacol Toxicol 2002;42:25-54.

29. Liberio SA, Pereira AL, Dutra RP, Reis AS, Araújo MJ, Mattar NS, et al. Antimicrobial activity against oral pathogens and immunomodulatory effects and toxicity of geopropolis produced by the stingless bee Melipona fasciculata Smith. BMC Complement Altern Med 2011;11:108.

30. Varthamanan J, Jayanthi B. Evaluation of antioxidant and antimicrobial activity of stingless bee propolis (Tetragonula iridipennis) of Tamilnadu, India. Int J Pharm Pharm Sci 2014;6(8):81-5.

31. Khalil ML. Biological activity of bee propolis in health and disease. Asian Pac J Cancer Prev 2006;7(1):22-31.

32. Saxena P, Pant VA, Wadhwani KK, Kashyap MP, Gupta SK, Pant AB. Potential of the propolis as storage medium to preserve the viability of cultured human periodontal ligament cells: An in vitro study. Dent Traumatol 2011;27(2):102-8.

33. Pileggi R, Antony K, Johnson K, Zuo J, Shannon Holliday L. Propolis inhibits osteoclast maturation. Dent Traumatol 2009;25(6):584-8.

34. Buttke TM, Trope M. Effect of catalase supplementation in storage media for avulsed teeth. Dent Traumatol 2003;19(2):103-8.

35. Ozan F, Tepe B, Polat ZA, Er K. Evaluation of in vitro effect of Morus rubra (red mulberry) on survival of periodontal ligament cells. Oral Surg Oral Med Oral Pathol Oral Radiol Endod 2008;105(2):e66-9.

36. Tavassoli-Hojjati S, Aliasghar E, Babaki FA, Emadi F, Parsa M, Tavajohi S, et al. Pomegranate juice (Punica granatum): A new storage medium for avulsed teeth. J Dent (Tehran) 2014;11(2):225-32.

37. Pounikar Y, Jain P, Khurana N, Omray L, Patil S, Gajbhiye A. Formulation and characterization of Aloe vera cosmetic herbal hydrogel. Int J Pharm Pharm Sci 2012;4(4):85-6.

38. Rajendran P, Varghese NO, Varughese JM, Murugaian E. Evaluation, using extracted human teeth, of Ricetral as a storage medium for avulsions - An in vitro study. Dent Traumatol 2011;27(3):217-20.

39. Udoye CI, Jafarzadeh H, Abbott PV. Transport media for avulsed teeth: A review. Aust Endod J 2012;38:129-36.

40. Pohl Y, Tekin U, Boll M, Filippi A, Kirschner H. Investigations on a cell culture medium for storage and transportation of avulsed teeth. Aust Endod J 1999;25(2):70-5.

41. Pohl Y, Filippi A, Kirschner H. Results after replantation of avulsed permanent teeth. II. Periodontal healing and the role of physiologic storage and antiresorptive-regenerative therapy. Dent Traumatol 2005;21(2):93-101. 